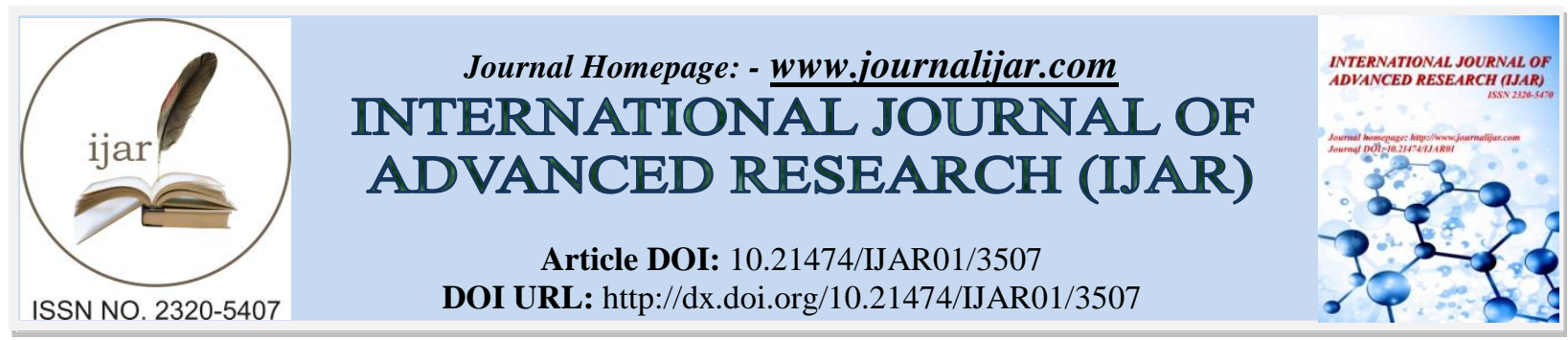

RESEARCH ARTICLE

\title{
STRATEGIC RESOURCES FOR SUSTAINABLE COMPETITIVE ADVANTAGE.
}

\author{
*Jumadi and Samsul Bakri. \\ Lecturer at the Economics Faculty of Widya Mataram Yogyakarta University.
}

\section{Manuscript Info}

Manuscript History

Received: 15 January 2017

Final Accepted: 13 February 2017

Published: March 2017

Key words:-

SCA (sustainable competitive advantage), $R B V$ (resources based

view), Valuable, Rare, Not Inimitable, Not Substitute, firm, EXSTRIM

\begin{abstract}
Companies are trying to position ourselves and try to have a sustainable competitive advantage, by leveraging the strength to exploit opportunities and neutralize threats, and can avoid or fix vulnerabilities that exist in the company. The gain the competitive advantage is the influenced by two factors, there are Internal environment and the external environment. Internal environment are important elements in the company. The Analysis of internal environment beneficial for the company, especially the resource analysis. This analysis is done for internal resource can be strength of the company, but also can be a source of weaknesses. Terms of resources can be a force if these resources are managed and empowered well, but on the contrary, if internal resources are not managed and controlled properly it will be the weaknesses of the company. Companies can achieve competitive advantage through resource, resources the company has four criterion the namely of Valuable, Rare, Low Inimitable Non- substitute (VRIN). However, based on this study Authors to identified resource from VRIN into EXSTRIM. The resources EXSTRIM that means of: Excellent, Not Substitute, Not Trade, Rare, Not Inimitable, Mover \& Modification can be the strategic resource configuration in the company to creating a sustainable competitive advantage (SCA).

Copy Right, IJAR, 2017, All rights reserved.
\end{abstract}

\section{Introduction:-}

Strategies management become indispensable in managing fluctuating environmental conditions, the environment can affect to the performance and company's goals. The company's strategy is formulated at three levels: operational level, functional level and strategic level, in the context of industry competition, the main concern is the strategic level. Each level of the strategy in general in order to create a competitive advantage that includes; cost leadership, focus and strategy that differentiate it from other companies Porter (1991). A business manager should be able to analyze the environment to understand opportunities and threats facing. Organizations need to build strength and improve weaknesses; this process is not just a single step, but a process that includes various steps. One of them is the scanning, the business situation, which, according to Albright (2004) scanning is an internal communication to get information relevant external information on the Issues of potential influence on corporate decision-making process in order to face the competition. The company may face competition when companies that have a sustainable competitive advantage by harnessing the power companies to exploit opportunities and neutralize the threat while avoiding or fixing a weakness or so-called analysis 'SWOT'. Porter's Five Force Model, Porter conducted an analysis of the competitiveness of the industry, which is affected by the five forces that emphasizes analysis of existing industrial structures. The Five forces such as; bargaining power of suppliers, bargaining power with customers, the strength of the threat of new entrants, as well as the strength of the threat from competitors as 
well as existing industry. While Porter framework has provided many useful insights both practitioners and researchers to concentrate on external analysis 'OT' nevertheless still experiencing some significant problems. The same thing Porter (1991), Valentin (2001) the SWOT analysis is an analytical tool for the environment that identify strengths weakness opportunities and threat for the company. The business strategy is a way to master the wide expertise and managing a company's profit with its surroundings. To realize that all companies should determine the factors which might be in the face of competition once expected to be used to win the competition? One factor that can be used to win the competition is a strategic resource company. Determine the combination of the company's strategic resources is not easy, but if it is done well and seriously then the combination can be achieved with either. The company's strategic resource that can be used to win the competition must be resources that have a competitive advantage compared to the resources owned by other companies.

\section{Understanding Resources:-}

Many definitions of resources raised by the experts which is according to Barney (1991) Barney define resource company covers all assets, capabilities, organizational processes, firm attributes, information, knowledge, which is controlled by the company. According to Anderson (2007) the resource can be divided into internal and external resources, external resources consist of relations with actors outside the company; customers and suppliers as well as its reputation. Javad \& Carlos (2010) introduced the idea that the company should be analyzed in terms of resources, not only in terms of its products alone. According to resources based view (RBV), resources are defined as: anything that can be regarded as a strength or weakness of a particular company. Resource companies as a factor in the company and are owned or controlled by the company. The resource is generally defined as "all assets, capabilities, organizational processes, firm attributes, information, and other knowledge that can be controlled by the company, resource as an asset or an input to production tangible or intangible owned by an organization and can be controlled, or in access to a semi-permanent.

\section{Resources Advantage:-}

According to Anderson (2007) special ability to create such varied resources management, entrepreneurial and dynamic capability has been used to describe the ability to generate strategic resources. Furrer at.al (2008) indicates that the resource-based grouping took the example of a bank that explains differences in corporate performance better than the market grouping based products. However, market-based group still provides explanations of the significance of the difference in performance in two of the three performance measures used. Meanwhile, according to Grant (1991) by using the difference between the resources and capabilities, resources are tangible or intangible assets, and capabilities are the ability generated from these assets. Anderson (2007) the resources can lead management capabilities such as the ability of the market, production capabilities, and the ability of innovation. To obtain optimal composition, the researchers suggest that the fit between the available resources of the company and the requirements of the product-market activity in terms of concepts such as generic strategies should be carried out it is appropriate revelation (Furrer at.al 2008). Resources Strategic Change, and Organizational Performance The concept of strategic Resources by Kraatz \& Zajac (2001) the resource that has an advantage can influence strategic changes to the company, the company can emphasize how resources can hinder or may lead to organizational learning in order to adapt. According to the opinion Banrey (1991) the latest research is a strategic resource is a resource company that is difficult to replicate. Meanwhile, according to Chaharbaghi \& Lynch; (1999) indicates that strategic resources are not the only applications that efficiently and effectively to provide the level of high competitiveness and ability to generate profits, but more important than that is how to make resources the mutual synergy so really widened superior resources and strategies for the company in realizing a sustainable competitive advantage. One way to the competitive advantage if the company has the dynamic strategic resource. The dynamic the resources within the company the combination of resources within the organization based on the time dimension will always be changing its composition, therefore, according to the authors' opinion that in order to realize the resource made resources that strategic managers must be able to combine existing resources in the company. According to Gro"ßler (2007) that resources are located will affect the performance capability of the organization / company (if not, they will not be located) there is a reciprocal process: the company's performance also affects resource and capability. Gro“ßler (2007) exemplifies the relationship between the ability to produce products with high quality and sales revenue as a performance indicator. Producing high quality (among other factors) affects the sales, which determines the sales revenue. Indicator of the understanding of strategic resources and its relation with the ability to improve the performance of the company. As Gro“ßler (2007) Barney (1991) found a strategic resource must have at least four major characteristics, namely: Durable, has a positive long-term effect on the company's strategic position; Non-tradable, it is impossible for competitors to easily afford; Non-applicable, it is impossible for 
competitors to easily duplicate or copy them; Non substitutable, it is impossible for competitors to easily find a replacement.

Meanwhile Barney (1991) that a strategic resource that can create competitive advantage and sustainability performance is a resource that has the following criteria: Valuable (V): Resource-value, the resource company that has a value that is able to set up the company in creating market opportunities and can reduce the challenges that exist in the market. Rare (R): The resources are scarce (unique), whose existence is difficult to find the resources and these resources are unique and not shared with other companies. Imperfect imitation (I): The resource that is difficult to imitate, this resource is difficult to imitate by other companies. Non-substitutability (N): The resources irreplaceable, resources in the other companies are difficult replacement to match.

Based on several definitions of strategic resources there is a difference between an expert opinions with another expert opinion, the difference is due to the perspective and different educational backgrounds. Therefore, the author tries to back describe strategic resources to get a thread or a new definition of the strategic resources. But before describing the author or authors redefine about strategic Resources will provide an overview of some of the definitions neighbor Strategic resources being addressed by some experts that will be displayed in the following table.

Table :- Definition of Strategic Resources

\begin{tabular}{|l|l|l|}
\hline No & Author & Definition \\
\hline 1 & Banrey (1991) & Business resources and difficult to imitate \\
\hline 2 & Black and Boal (1994) & $\begin{array}{l}\text { Identify how the performance of the company and its } \\
\text { sustainability depends on the uniqueness, rarity. }\end{array}$ \\
\hline 3 & Chaharbaghi \& Lynch (1999) & $\begin{array}{l}\text { Strategic resource not only the application of efficient and } \\
\text { effective to provide the level of high competitiveness and } \\
\text { ability to generate profits, but more important than that is } \\
\text { how to make resources the mutual synergy that really } \\
\text { widened resource excellence and strategic for the company } \\
\text { in realizing SCA }\end{array}$ \\
\hline 4 & Kraatz \& Zajac (2001) & $\begin{array}{l}\text { Resources that have the advantage may affect strategic } \\
\text { change in the company, the company can emphasize how } \\
\text { resources can hinder or may lead to organizational learning } \\
\text { in order to adaptation }\end{array}$ \\
\hline 5 & Anderson (2007) & $\begin{array}{l}\text { Special ability to create such varied resources management, } \\
\text { entrepreneurial and dynamic capability has been used to } \\
\text { describe the ability to generate strategic resources. }\end{array}$ \\
\hline
\end{tabular}

Based on Banrey (1991) the identification of the resources are: V: Valuable, R: Rare, I: Not Inimitable N: Not Substitute, Black and Boal (1994) identification of the resources are VRIO that mean are V: Valuable, R: Rare, I: Not Inimitable, O; Organization Orientation, they are differences existing definition. So the Author can the conclusion of the strategic resources is "The unique resource obtained through a process that is adaptive and proactive to spearhead (guns) as a means to win the competition and excellence continuous competitiveness. This resource should have the first criteria; excellent namely resource superior or resources are: Excellent, Second: Not Substitute are resources that not be replaced, Third: Not Trade resources that are not easily assessed by monetary or not be traded, Fourth: rare is a scarce resource that is difficult to obtain, Fifth: Not Inimitable that the resources that are difficult to imitate by other companies, Sixth: Mover \& Modification is easy to be adapted to the dynamically changing environment, means that in the past, now becoming a strategic resource, but not necessarily in the future come can be a strategic resource back. Therefore, if the company to gain a sustainable competitive advantage the company must make resource adaptive, proactive and reactive to the environment. Based on the above, the Authors refer to as strategic resources are: EXSTRIM or the means of: Excellent, Not Substitute, Not Trade, Rare, Not Inimitable, Mover \& Modification.

Anderson (2007) The ways to realize the strategic resource contribution-based view of research taking the difference in the configuration of resources between companies, if there is a description of how these strategic resources are developed, the discussion usually focuses on direct investments as a way to obtain strategic resources. However, differences in the configuration of resources between companies can also be explained by factors other than the difference in making investment decisions. Usually the activity that takes place within the company in terms of 
organizational processes and activities carried launching products in the market and can also develop resources in order to obtain strategic resources. Thus, a strategic resource can be obtained in three ways:

1. Through direct investment;

2. Through the process of organization, and

3. Through the activities undertaken in the product markets.

Barney (1991) identifies the barriers that used to barrier process of imitation, the things that will be used when analyzing barriers to imitation are:

1. The social complexity;

2. Ambiguity causal,

3. Conditions unique history

Social complexity refers to the intangible factors such as social and cultural relations, while the causal ambiguity exists when the relationship between resources and competitive advantage is unknown. Conditions unique history confirms that each company is a unique entity and that the possibility of acquiring the resources depending on the time point, where and when to get those resources.

\section{Strategic Concept advantage:-}

According to Barney (2002) the company will gain a competitive advantage if the company's strategy and values which not be done by the company's competitors. Strategic advantage, on the other hand, covers a broader perspective in which this matter, so Chaharbaghi \& Lynch (1999) include the following:

1. Provide the organization with a unique ability to develop strategic directions that create new opportunities and future competitive environment.

2. Is a source of leadership resources in one or more of the products on the market.

Sustainable competitive advantage (SCA) is a process that needs to compete today without compromising the ability of organizations to meet the requirements to compete in the future. Chaharbaghi \& Lynch (1999) the process of developing such an organization as a dynamic concept, which covers the basics of the following:

1. Sustainable Competitive Advantage is a conservation-oriented as the organization does not have unlimited resources. Given these limitations, conscious management of existing resources is needed.

2. Sustainable Competitive Advantage is based on the needs of the organization in which economic activities should be concerned with the needs of the market for goods and services resulting from economic activity.

3. Sustainable Competitive Advantage is future-oriented, placing itself outside day-to-day management of longterm development resources to bring strategic advantages

4. A Strategic Advantage is the standard for corporate renewal, it is very dependent and influenced by, the development and timely introduction to strategic resources.

Based on the results from the description above one of the factors that can be used to create a sustainable competitive advantage SCA is a resources firm. Configuration was good between resources is expected to be decisive to the sustainable competitive advantage.

\section{Conclusion:-}

Based on the discussions that have been submitted at the beginning to the end that was found disagreement among experts on the categorizing of corporate resources is generally grouped into three categories, namely: physical, tangible resources, intangible resources and human resources. A good combination between the three elements contained in these resources is expected to establish a sustainable competitive advantage SCA. For the competitive advantage for the company to be created in earnest with how to configure the use of the existing resources within the company to the optimum. Appropriate combination or selection of the resources for the company is the main capital in determining the level of a sustainable competitive advantage. The resources based view RBV has contributed much to the formation of a strategic resource in promoting a sustainable competitive advantage. Resources that have a sustainable competitive advantage if they meet the criterion VRIN namely; Valuable, Rare, Non Inimitable and Non Substitute. Meanwhile, according to the Authors that strategic Resources should have the criterion: first Excellent is the resource superior or resources excellent, Second: not Substitute is the resources that not be replaced, Third: Not trade is the resources that are not easily assessed by monetary or not be traded, Fourth: Rare is the resource that is difficult to obtain, Fifth: Not Inimitable is the resources that is difficult to imitate by other companies, Sixth: Mover \& Modification is easy to be adapted to the dynamically changing environment, means 
that in the past, is now becoming a strategic resource, but not necessarily in the past that will come can be a strategic resource back. Based on the above, the Authors refer to as a resource to resource strategic are the EXSTRIM resources criterion.

\section{Recommendation:-}

The first performed by the expert company strategy is the identification of all the factors that may affect its business. In this process, that important to know and to do is the related to internal activities involved in the business, this includes all the systems of internal structure, strategies used, and the culture of the organization. The company's activities will interact with the environment components outside the company such as customers, competitors, and supplier; in addition it includes all parties (stakeholders) such as trade unions, media, and government. Competition has entered a new era with the constant changes. The infrastructure problems that disrupt the organization can't be solved effectively without resource-based strategy is therefore necessary to incorporate the following principles:

1. Strategic resources must be regenerated more quickly than those used by other companies

2. The resources must be used more quickly excel

3. Basis of resources should be considered to be invested faster than the rate of acceptance of the environment (adaptive) and proactive to realize resource from VRIN criterion to $\mathrm{EX} \mathrm{STR} \mathrm{T}$ to targeting in the sustainable competitive advantage (SCA).

\section{References:-}

1. Anderson Jim, 2007, "A Holistic Approach to Acquisition of Strategic Resources", Journal of European Industrial Training Vol. 31 No. 8, 2007 pp 660-677

2. Albright Kendra S., 2004,"Environmental Scanning: Radar for Success may", the information Management Journal.

3. Barney, J, 1991, ”Firm Resources and Sustainable Competitive”, Journal of Management, Vol. 17. No. 1 pp 99120.

4. Barney, J. (2002), "Strategic management: from informed conversation to academic discipline", Academy of Management Executive, Vol. 16, pp. 53-7.

5. Black Janice a. And Boal Kimberly B, 1994, Strategic Resources: Traits, Configurations and Paths to Sustainable Competitive Advantage, Strategic Management Journal, Vol. 15, 131-148.

6. Chaharbaghi Kazem, Lynch Richard, 1999, "Sustainable Competitive Advantage: Towards a Dynamic Resource-Based Strategy", Management Decision, pp, 45-50

7. Furrer, Sudharshan, Thomas, Alexandre, 2008, "Resource configurations, generic Strategies, and Firm Performance Exploring the Parallels Between Resource-Based and Competitive Strategy Theories in a New Industry”, Journal of Strategy and Management Vol. 1 No. 1, pp. 15-40

8. Grand R, M, 1991, "The Resources Based Theory, of Competitive Adventage: Implication for Strategy Formulation", California Management Review.

9. Gro“ßler Andreas, 2007, "A dynamic view on strategic resources and capabilities applied to an example from the manufacturing strategy literature”, Journal of Manufacturing Technology Management Vol. 18 No. 3, pp. 250-266

10. Javad Abadi, Carlos Cardon, 2010, "Developing a Framework for Identification and Analysis of the Strategic Resources and Capabilities in Supply Chains", The 8th International Conference on Logistics and SCM Research, BEM Bordeaux Management School.

11. Kraatz Matthew S. and Zajac Edward J, 2001, "How Organizational Resources Affect Strategic Change and Performance in Turbulent Environments": Theory and Evidence, Organization Science, Vol. 12, No. 5 pp. 632-657

12. Porter Michael E.,1991, "Towards a Dynamic Theory of Strategy", Strategic Management Journal, Vol. 12, Special Issue: Fundamental Research Issues in Strategy and Economics (Winter, 1991), pp. 95-117

13. Valentin E.K, 2001, “Swot Analysis From Resources Based View”, Journal of Marketing Theory and Practice, pp 54-69. 